\title{
Imaging Neuronal Populations in Behaving Rodents: Paradigms for Studying Neural Circuits Underlying Behavior in the Mammalian Cortex
}

\author{
Jerry L. Chen, ${ }^{1}$ Mark L. Andermann, ${ }^{2}$ Tara Keck, ${ }^{3}$ Ning-Long Xu, ${ }^{4}$ and Yaniv Ziv ${ }^{5}$ \\ ${ }^{1}$ Brain Research Institute, University of Zurich, Zurich, Switzerland CH-8057, ${ }^{2}$ Division of Endocrinology, Department of Medicine, Beth Israel Deaconess \\ Medical Center, Harvard Medical School, Boston, Massachusetts 02215, ${ }^{3}$ MRC Centre for Developmental Neurobiology, King's College London, London SE1 \\ 1UL, United Kingdom, ${ }^{4}$ Janelia Farm Research Campus, Howard Hughes Medical Institute, Ashburn, Virginia 20147, and ${ }^{5}$ Clark Center for Biomedical \\ Engineering and Sciences, Department of Biology, Stanford University, Stanford, California 94305
}

Understanding the neural correlates of behavior in the mammalian cortex requires measurements of activity in awake, behaving animals. Rodents have emerged as a powerful model for dissecting the cortical circuits underlying behavior attributable to the convergence of several methods. Genetically encoded calcium indicators combined with viral-mediated or transgenic tools enable chronic monitoring of calcium signals in neuronal populations and subcellular structures of identified cell types. Stable one- and two-photon imaging of neuronal activity in awake, behaving animals is now possible using new behavioral paradigms in head-fixed animals, or using novel miniature head-mounted microscopes in freely moving animals. This mini-symposium will highlight recent applications of these methods for studying sensorimotor integration, decision making, learning, and memory in cortical and subcortical brain areas. We will outline future prospects and challenges for identifying the neural underpinnings of task-dependent behavior using cellular imaging in rodents.

\section{Introduction}

A fundamental goal of modern neuroscience is to understand the basic computations performed by the mammalian cortex and how these computations are modified by behavioral context. Whereas the study of the cortex dates back to the time of Aristotle and Galen, it is apt and humbling that in the year 2009, a Howard Hughes Medical Institute conference was organized to debate the basic question, "What does the cortex do?"

Specifically, in what ways and by which neural mechanisms does the cortex contribute to the vast repertoire of mammalian behaviors and cognitive processes? Although we know that different cortical areas are specialized for different sensory, motor, and cognitive functions, there is a growing consensus that the basic structural organization of cortical circuits and the fundamental computations performed by these circuits are essentially

Received July 31, 2013; revised Sept. 12, 2013; accepted Sept. 13, 2013.

J.L.C. was supported by a Forschungskredit from the University of Zurich (Grant 541541808) and a fellowship from the National Science Foundation, International Research Fellowship Program (Grant 1158914). M.L.A. was supported by the Smith Family Foundation, the Pew Scholars Program in the Biomedical Sciences, the Klarman Family Foundation, the Boston Nutrition Obesity Research Center, and the American Federation for Aging Research. T.K. was supported by the Medical Research Council and the European Research Council. N.-L.X. was supported by the Howard Hughes Medical Institute. Y.Z. was supported by a fellowship from the Machiah Foundation and research grants from the Paul G. Allen Family Foundation and the National Institutes of Health (Grants DP10D003560, R21AG038771, and R21MH099469). We thank J. N. Kerr for comments on this manuscript and S. Barnes, L. J. Kitch, and T. Knopfel for figure contributions.

Y.Z. has ownership interest and consulting fees related to Inscopix, Inc., a company that produces one of the miniature microscopes reported in this manuscript. The remaining authors declare no competing financial interests.

Correspondence should be addressed to Jerry L. Chen, Brain Research Institute, University of Zurich, Winterthurerstrasse 190, Zurich, Switzerland CH-8057. E-mail: jerry.chen@hifo.uzh.ch.

DOI:10.1523/JNEUROSCI.3255-13.2013

Copyright $\odot 2013$ the authors $\quad 0270-6474 / 13 / 3317631-10 \$ 15.00 / 0$ conserved across mammals. The anatomy of cortical circuits suggests that they are built to process information in a highly flexible manner. A given cortical circuit receives a wide variety of inputs carrying information regarding the current context of the external world, the needs and goals of the body, and the insights of prior experiences for achieving specific goals in different contexts. The determination of which sources of input will guide a given cortical computation, and where the cortical circuit will relay its output, is guided by a highly diverse variety of types of local inhibitory interneurons and of neuromodulatory and feedback signals.

Until this point in time, a large portion of research on cortical function during behavior has been conducted using well established technologies such as single-cell electrophysiological recordings. These experiments take a reductionist approach, by interrogating one circuit element at a time under a limited number of controlled task conditions. Despite a considerable amount of progress, the trial-to-trial variability often observed during recordings, potentially reflecting learning, internal motivation, or external task structure, presents challenges for understanding how such processes are manifested in the cortex. Given this issue, interest has grown in performing large-scale measurements of population activity to provide the sampling size to overcome such hurdles (Kandel et al., 2013). Whereas large electrode arrays to simultaneously record large populations of neurons represent a step in this direction (Buzsáki, 2004), what is further needed to understand the role of each element within the circuit is the ability to repeatedly sample these neurons along a variety of behavioral conditions with a resolution down to individual synapses and to assess their genetic and anatomical identity. 
Recently, parallel developments in one- and two-photon imaging technology, sensors of neuronal activity, genetic tools, and behavioral methods have converged to provide the opportunity for performing such experiments in the rodent system. Although these methods have been reviewed individually elsewhere, here we specifically focus on how they can be integrated in the application of oneand two-photon calcium imaging to the study of cortical microcircuits across behavioral contexts. Cellular imaging in rodents can provide a platform for highthroughput, high-yield, genetically accessible experiments that offer a valuable complementary approach to electrophysiological methods for detangling the local microcircuits underlying cortical computations. Rodent cortex is smooth and thin and contains an elaborate network of relatively compact cortical areas. As such, complete local sampling of the same volume of cells, and/or of multiple cortical layers and brain areas, can be achieved across days and weeks in the same experiment. This has seen extraordinary progress in the last 3 years, and we hope that by outlining the applications, advantages, and outstanding challenges of this approach, we will provide a succinct entry point for researchers interested in beginning to use imaging to break new ground in understanding the cortical microcircuits underlying flexible, context-dependent neural computation.

\section{Tools for functionally dissecting neuronal circuits in rodents}

Two-photon fluorescence microscopy is the most widely used tool for optically measuring neuronal activity deep in the brain with cellular and subcellular resolution (Helmchen and Denk, 2005; Kerr and Denk, 2008). Two-photon calcium $\left(\mathrm{Ca}^{2+}\right)$ imaging using $\mathrm{Ca}^{2+}$-sensitive fluorescent indicators measures changes in intracellular $\mathrm{Ca}^{2+}$ concentration as a readout for suprathreshold and subthreshold neuronal activity. Standard two-photon microscopes use mirror-based scanning to monitor calcium signals in full-frame two-dimensional fields of views at rates up to $\sim 40 \mathrm{~Hz}$, whereas the recent use of random access point scanning through acousto-optic deflectors can sample populations of $\sim 100$ neurons at rates of up to $\sim 500 \mathrm{~Hz}$ in two and three dimensions (Grewe et al., 2010; Katona et al., 2012) (Fig. 1a). Calcium signals measured simultaneously across hundreds of neurons in vivo have been used to probe the dynamics and functional organization of neuronal circuits, and powerful computational tools have been developed to analyze calcium imaging data to infer spiking activity from calcium transients (Yaksi and Friedrich, 2006; Greenberg et al., 2008; Mukamel et al., 2009; Vogelstein et al., 2009,2010; Grewe et al., 2010; Cheng et al., 2011), to correlate activity to stimulus or behavior parameters (Seelig et al., 2010; Miri et al., 2011; Huber et al.,
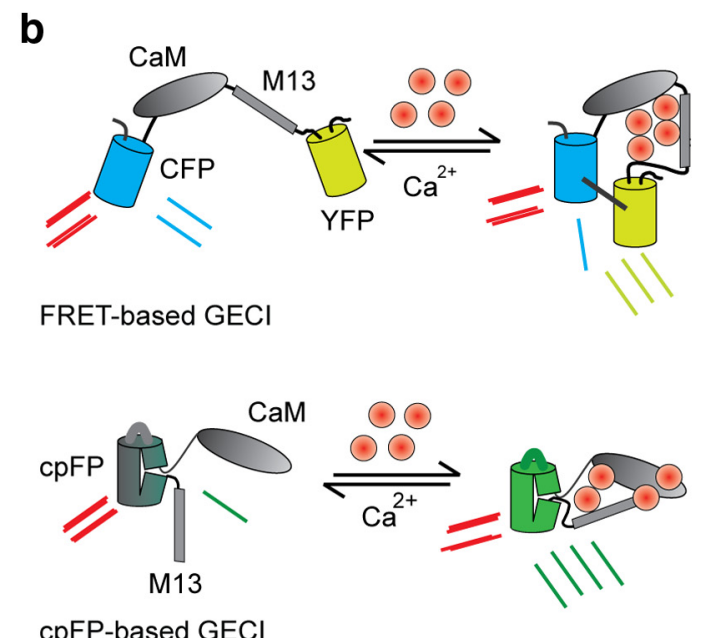

cpFP-based GECl
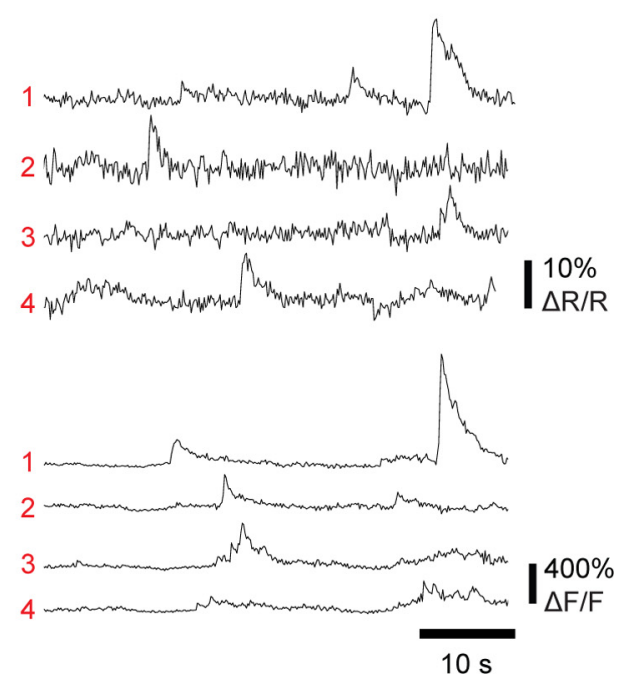

Figure 1. In vivo two-photon calcium imaging of neuronal activity. $\boldsymbol{a}$, Schematic of a conventional, mirror-based scanning two-photon microscope for in vivo imaging. $\boldsymbol{b}$, Schematic of GECls wherein calcium binding produces a conformation change in the complex (CaM-M13). For FRET-based GECls, the fusion of a FRET pair (CFP/YFP) allows the conformational change to be measured as an increase in FRET efficiency during two-photon excitation. For cpFP-based GECls, the fusion of a cpFP allows the conformational change to be detected as an increase in quantum yield of cpFP fluorescence [adapted from Knöpfel (2012) with (left) and calcium traces of indicated cells (right). For FRET-based GECls, calcium signals are measured as the relative change in the $\mathrm{YFP} / \mathrm{CFP}$ ratio $(\Delta \mathrm{R} / \mathrm{R})$. For cpFP GECls, calcium signals are measured as the relative change in fluorescence intensity $(\Delta \mathrm{F} / \mathrm{F})$.

2012), and to correct for brain motion artifacts induced by movement (Thévenazet al., 1998; Dombeck et al., 2007; Greenberg and Kerr, 2009; Bonin et al., 2011). The subcellular resolution of twophoton microscopy has been used to map the synaptic inputs and outputs of single neurons in vivo (Jia et al., 2010; Chen et al., 2011; Petreanu et al., 2012; Xu et al., 2012; Glickfeld et al., 2013).

Calcium imaging has predominantly been performed using synthetic calcium indicators, but recent improvements in genetically encoded calcium indicators (GECIs) are now beginning to rival their synthetic counterparts in dynamic range and sensitivity to single action potentials (Horikawa et al., 2010; T. W. Chen et al., 2013). These improved GECIs consist of a calmodulin complex (which undergoes a conformational-state transition during $\mathrm{Ca}^{2+}$ binding) fused with a conformation-sensitive fluorescent protein reporter: either Förster resonance energy transfer (FRET) protein pairs for Yellow Cameleon-class indicators or circularly permuted fluorescent proteins (cpFPs) for GCaMP class indicators (Fig. 1b,c) (Knöpfel, 2012). The benefits of GECIs compared 

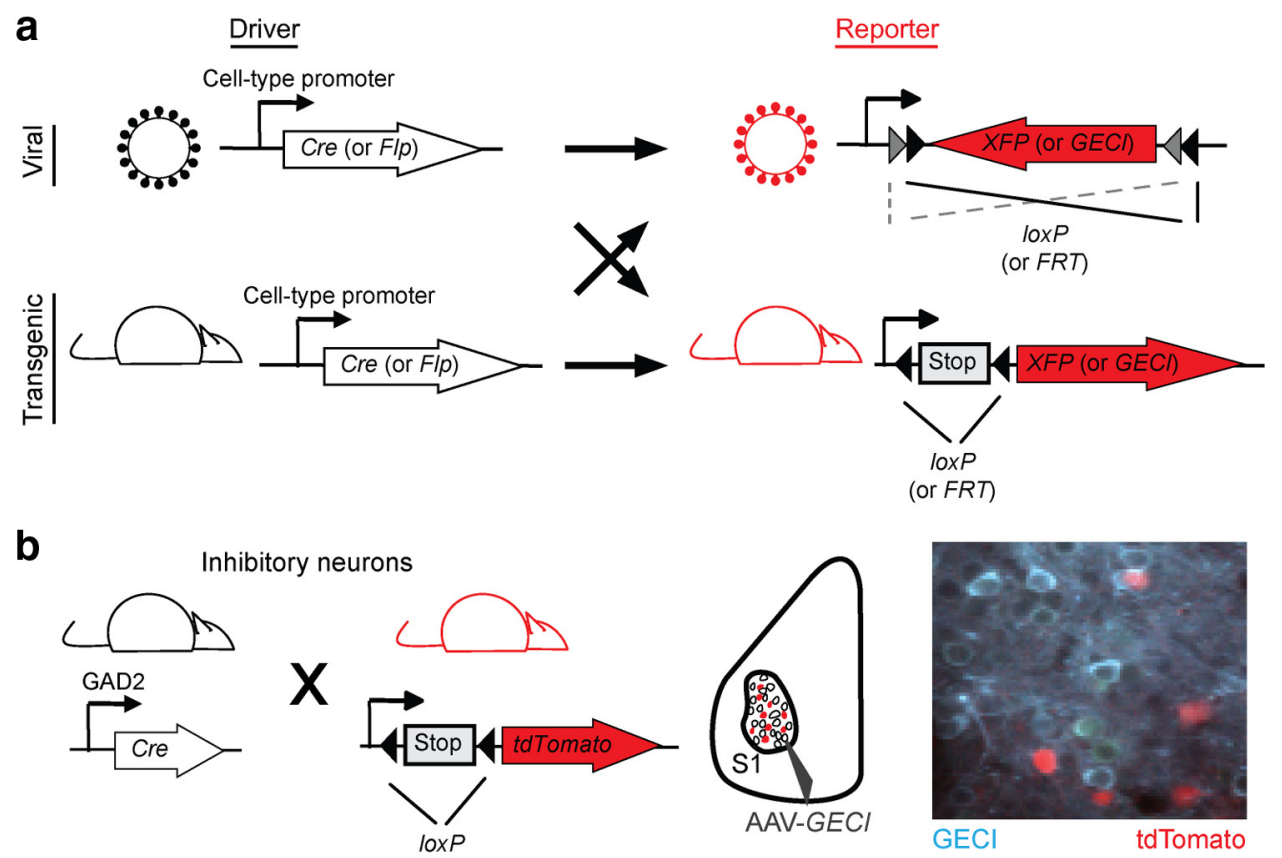

Long-range projection neurons
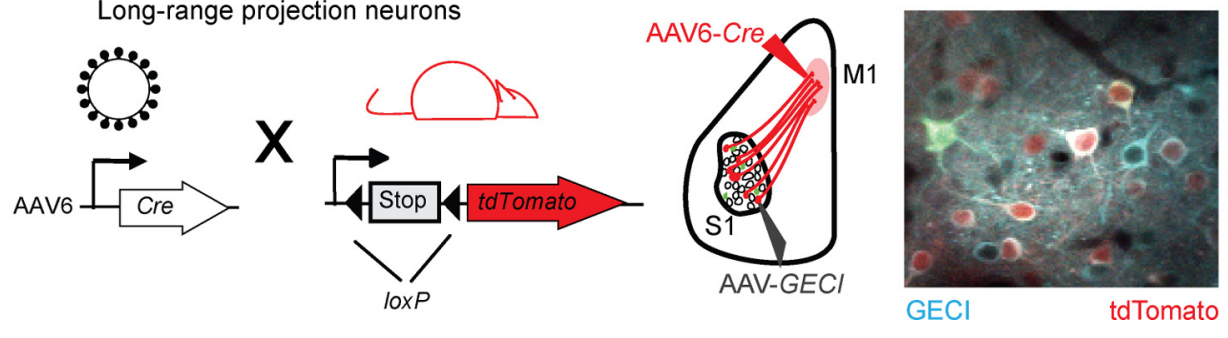

Figure 2. Genetic tools for dissecting neuronal circuits. $\boldsymbol{a}$, Site-specific recombinase systems for use to identify neuronal cell types. Viral constructs or transgenic lines driving Cre or Flp recombinase expression under a cell-type-specific promoter can be combined with a reporter for conditional, Cre-dependent, or Flp-dependent fluorescent protein or GECl expression. $\boldsymbol{b}$, Examples of strategies to identify molecularly and anatomically defined cell types for calcium imaging. Inhibitory (top) or long-range projection (bottom) neurons are labeled using transgenic crosses or retrograde viruses, respectively. Left, Genetic crosses. Middle, Viral injections for imaging in primary somatosensory cortex (S1). Right, In vivo images of GECI-expressing neurons with cell types identified.

with synthetic indicators are numerous. Researchers are no longer restricted by the narrow window of synthetic indicator expression to conduct acute imaging experiments where animals are expected to behave immediately after surgical procedures (Dombeck et al., 2009; Andermann et al., 2010; Komiyama et al., 2010; Hira et al., 2013). The limited recovery time in acute experiments presents potential confounds because of tissue inflammation, immune response, and residual anesthesia. Data collection can be maximized in valuable animals where time and effort have been invested in behavioral training by sampling different populations across multiple imaging sessions. Individual neurons can be followed chronically during learning and plasticity (Mank et al., 2008; Andermann et al., 2010; Huber et al., 2012; Margolis et al., 2012) with the implantation of a cranial window (Holtmaat et al., 2009) in animals where stable GECI expression across thousands of neurons is achieved through viral delivery or transgenic lines (Chen et al., 2012; Zariwala et al., 2012). The transmission and integration of calcium signals along subcellular compartments can also be measured through expression of cytosolic GECIs (Petreanu et al., 2012; Xu et al., 2012; T. W. Chen et al., 2013; Glickfeld et al., 2013; Kaifosh et al., 2013) and GECIs modified with localization tags (Nagai et al., 2002; Mao et al., 2008).

Studies relating population activity to neuronal cell types or anatomic connectivity have been achieved by combining calcium imaging with retrospective methods such as immunohistochemistry (Kerlin et al., 2010; O'Connor et al., 2010b; Langer and Helmchen, 2012), electron microscopy (Bock et al., 2011), or slice electrophysiology (Hofer et al., 2011; Ko et al., 2011, 2013). The large palette of genetic tools available in the rodent provides unique opportunities to functionally dissect defined circuit components in the mammalian cortex online. Broadly, a strategy can be used in which complementary fluorescent proteins are expressed in specific cell types that can be simultaneously resolved during two-photon calcium imaging (Fig. 2). Molecularly defined neuronal cell types (e.g., inhibitory interneurons) can be identified in transgenic lines in which cell-type-specific promoters drive expression of fluorescent proteins. The use of DNA site-specific recombinases, such as Cre/loxP and Flp/FRT systems, can also be used to drive conditional expression of GECIs or fluorescent protein labels by crossing "driver" transgenic lines with "reporter" lines or delivery of Cre- or Flp-dependent viral constructs (Luo et al., 2008). Cell-type specificity can also be achieved through intersectional strategies combining Cre/loxP and Flp/FRT systems. Temporally induced expression of these recombinases or in utero gene delivery (LoTurco et al., 2009) can also be used to identify cell types defined by developmental origin (Li et al., 2012; Ohtsuki et al., 2012; Yu et al., 2012).

In addition to molecularly defined cell types, anatomically defined subpopulations can be identified using fluorescent 
tracers. Calcium imaging in combination with synthetic or viralbased retrograde tracers have proved to be useful in characterizing the functional responses of long-range projection neurons innervating a target area (Sato and Svoboda, 2010; Jarosiewicz et al., 2012; J. L. Chen et al., 2013). Synaptically connected neurons can be identified and monitored using monosynaptically restricted rabies virus expressing fluorescent proteins or GECIs (Wickersham et al., 2007; Osakada et al., 2011). Cre-dependent expression of specific viral components required for the infection, replication, and spread of the modified rabies can identify neurons providing inputs to specific neuronal cell types (Wall et al., 2010). In summary, in vivo two-photon calcium imaging combined with rodent genetics and anatomical tools provide unprecedented circuit-level access and throughput for studying the mammalian cortex.

\section{Head-fixed, sensory-guided decision making}

Stability is a fundamental requirement for imaging calcium dynamics in awake animals with standard two-photon microscopes. Inspired by experiments using a head-fixed, behaving monkey preparation, where head fixation and body restraint provide stability for electrophysiological recordings as well as a high degree of stimulus control and behavioral readout (Evarts, 1968; Wurtz, 1968), head-fixed, choice-based mouse behavior paradigms have been developed for optical imaging during behavior (Andermann et al., 2010; Komiyama et al., 2010; O'Connor et al., 2010b; Huber et al., 2012; Petreanu et al., 2012; Xu et al., 2012; J. L. Chen et al., 2013). In a typical nonlocomotive head-fixed task, the mouse receives a variety of sensory stimuli belonging to two different categories of outcomes, e.g., tactile objects of varying textures or objects at varying positions (O'Connor et al., 2010b; Huber et al., 2012; Petreanu et al., 2012; Xu et al., 2012; J. L. Chen et al., 2013), different odorants (Shusterman et al., 2011; Smear et al., 2011), or visual drifting gratings of different directions or orientations (Andermann et al., 2010; Histed et al., 2012; Lee et al., 2012). The animal's task is to determine which category a presented stimulus belongs to and respond with predefined actions not requiring body locomotion, e.g., licking a water port or pressing a lever to obtain reward.

Two versions of such tasks have been developed in head-fixed mice based on how the behavioral choices are made. One is the go/no-go task, in which an animal performs an action such as licking a water port to obtain a reward after "go" stimuli and withholds the action after "no-go" stimuli (O'Connor et al., 2010a). The second is the two-alternative forced-choice (2AFC) task (Mayrhofer et al., 2013; O'Connor et al., 2013), where an animal makes one out of two choices based on sensory stimuli, e.g., licking one of two water ports positioned to the left or right of the mouth. The key difference between the two paradigms is whether the sensory stimuli are always associated with actions that could lead to reward. In the go/no-go task, only the stimuli in go trials are potentially rewarding, whereas in the 2AFC task, both actions could lead to reward. Each task has its strengths and weaknesses depending on the questions being asked. For example, the no-go trials in the go/no-go task are particularly useful in isolating sensory responses without the potential influence of reward anticipation or response. However, animals performing the go/no-go task inevitably show response bias toward go stimuli, whereas in the $2 \mathrm{AFC}$ task, both categories of stimuli have equal or similar reward-predicting values. This is more suitable for experiments requiring symmetrical task structures, e.g., to examine reaction time. Compared with traditional maze or arena-based rodent behavior, head-fixed tasks provide a greater number of trials (hundreds) per session with improved statistical power. Mice can be trained to perform basic sensory discrimination tasks within 1-3 weeks. This short training duration combined with the capacity for high-throughput training of rodents makes it practical to perform experiments in which population activity can be compared in sets of rodents trained to different task conditions to identify task-dependent features of cortical processing (J. L. Chen et al., 2013).

The stable imaging afforded by head fixation in combination with the subcellular resolution of two-photon microscopy provides the unique opportunity to directly observe axonal and dendritic activity during behavior. Activity of long-range inputs can be isolated by imaging spiking-related calcium signals of axons in a region innervated by projection neurons from distant cortical or subcortical areas where GECI expression has specifically been induced. Specific questions regarding information transmission in the cortex can be addressed, such as, What information does a cortical circuit have access to and from where? For example, calcium imaging of vibrissal motor cortex (vM1) axons innervating barrel cortex (vS1) has demonstrated that vM1 sends information about whisking motor behavior directly to vS1 during active tactile sensation (Petreanu et al., 2012) and that, in the hippocampus, inhibitory neurons of the medial septum send multimodal sensory information about stimulus intensity to inhibitory neurons in CA1 (Kaifosh et al., 2013). The distinction can also be made between what information is computed within the local circuit versus what is inherited from elsewhere by comparing axonal signals in a given pathway with somatic signals in the upstream and downstream area. Comparisons of visual response properties of axonal projections from primary (V1) to higher (V2) visual areas with that of the local population in V1 and V2 suggest that some of the specialized visual responses that define V2 may, in fact, be computed and inherited from V1 (Glickfeld et al., 2013). Complementing work on axons, calcium imaging in dendrites has allowed us to address how these longrange input signals are integrated locally. Imaging of dendritic activity in vS1 during active tactile sensation suggests that dendrites can nonlinearly integrate long-range corticocortical input, such as from vM1, with ascending sensory input during behaviorally relevant computations (Fig. 3) (Xu et al., 2012). This finding emphasizes the need to study both dendritic- and circuit-level computation to understand cortical function.

\section{Head-fixed locomotion and virtual navigation}

While the head-fixed paradigms described above allow for the study of cortical activity during sensory-guided decision making, use of a spherical treadmill with head fixation (Dombeck et al., 2007) permits the measurement of processes occurring during behaviors involving locomotion in combination with controlled sensory stimuli (Fig. 4). Inspired by experiments initially performed in insects (Dahmen, 1980; Mason et al., 2001; Stevenson et al., 2005), this setup typically involves a head-fixed animal resting or walking on a Styrofoam ball that is raised with air and thus able to rotate as the animal moves. The movement of the floating ball is measured with optical sensors to provide information about the speed and direction of the locomotion. The relatively small mass of the mouse walking on the low-friction environment of the floating spherical treadmill minimizes the amount of forces applied against the head holder, allowing for stable imaging. This has opened new avenues for studies on the effects of locomotion on mammalian cortical function, which has previously been limited in larger mammals. 

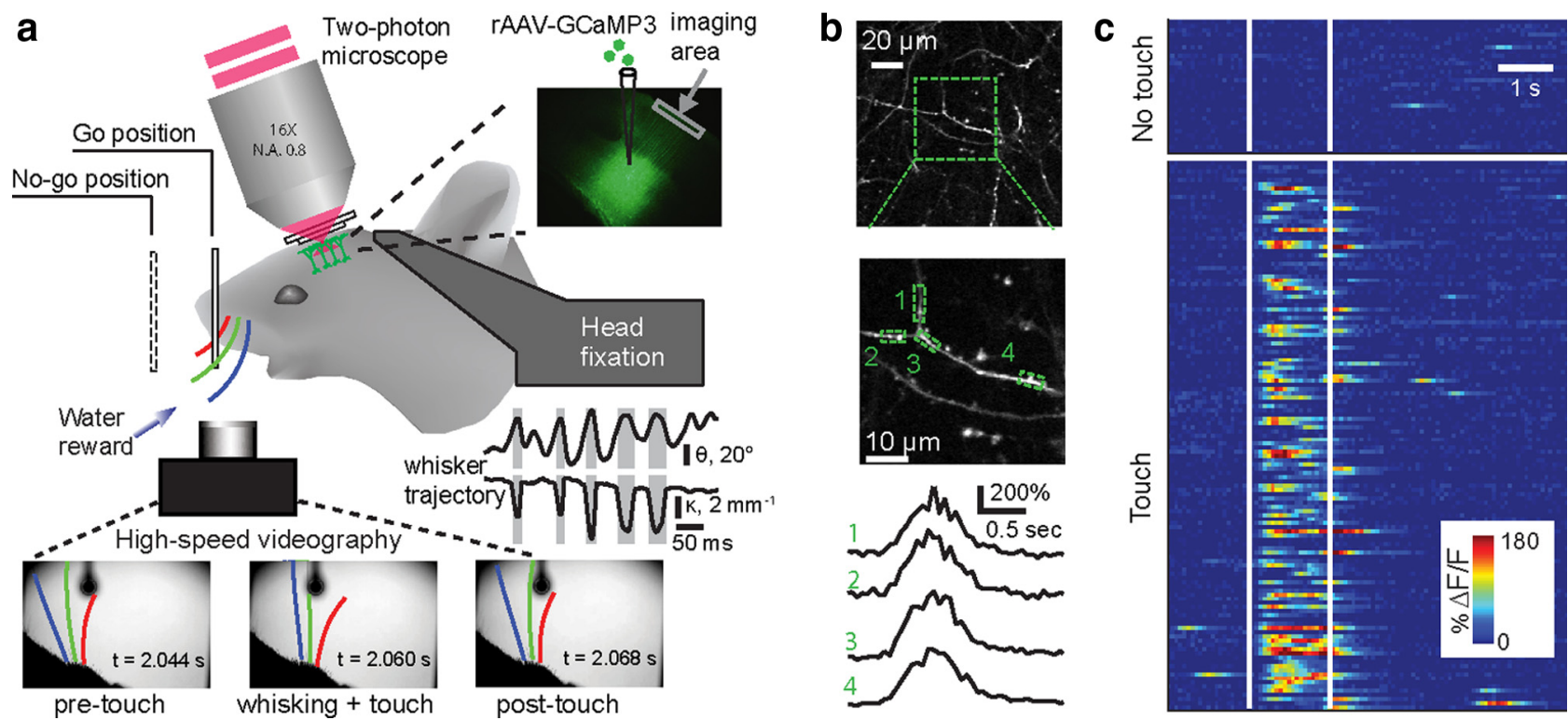

Figure 3. In vivo two-photon imaging of dendritic $\mathrm{Ca}^{2+}$ signals in task-performing mice. $\boldsymbol{a}$, Experimental setup; a head-fixed mouse performs a whisker-dependent object localization task under a microscope. The scanning laser beam (red) is focused on distal dendrites of GCaMP3-labeled neurons (green) through an imaging window. The mouse actively whisks to find the pole and makes a lick response (go) or withholds licking (no-go). Whisker motion was recorded with high-speed video (bottom) and quantified (whisker angle, $\theta$, and curvature change, $\kappa$; gray shows touch). Top left, Schematic showing two-photon imaging setup. Top right, GCaMP3 is expressed in deep layers of barrel cortex. N.A., Numerical aperture. $\boldsymbol{b}$, Dendritic tuft branches (top and middle) and Ca ${ }^{2+}$ signals ( $\Delta F / F$; bottom) from different subregions of a single branch (green dashed boxes). Middle panel is a magnified region in the top panel (green square box). $c$, $C$ olor raster of $C a^{2+}$ signals $(\Delta F / F)$ from all trials of a behavioral session sorted into touch (bottom block, with whisker- object contact) and nontouch (top block, without whisker- object contact) trials. [Adapted from Xu et al. (2012) with permission].
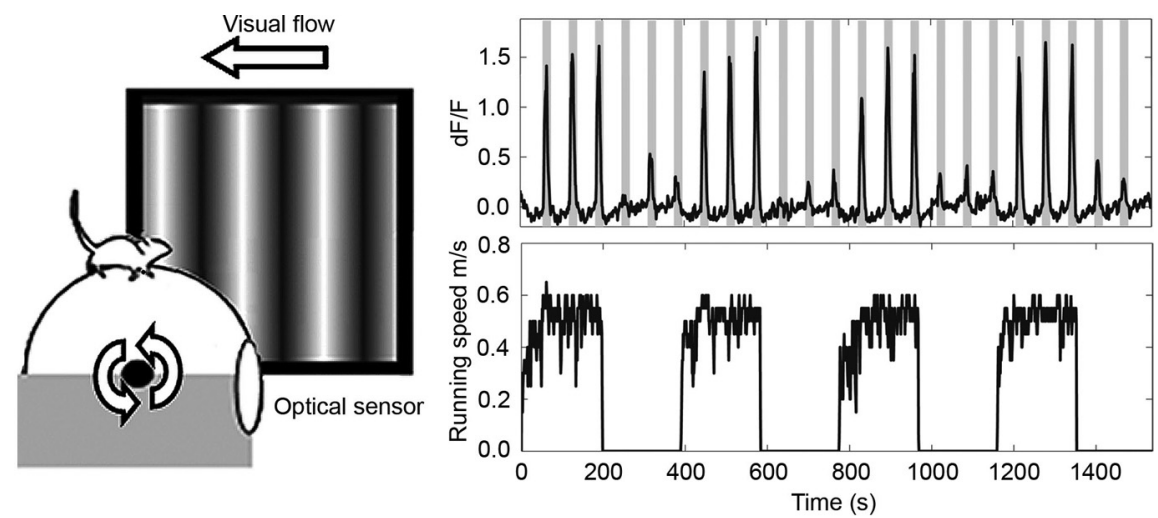

Figure 4. Visual responses are increased during locomotion. Left, Schematic of mouse on spherical treadmill with coupled visual feedback [adapted from Keller et al. (2012) with permission]. Right, Changes in fluorescence measured with GCaMP3 in a behaving mouse on a spherical treadmill equipped with a brake (top). Gray bars indicate periods of visual stimulation with drifting gratings. The running speed of the mouse (bottom) shows that visual responses are enhanced by increased running speed.

rect motor-related inputs to V1 play a role in this modulation of visual responses remains to be seen.

Imaging population activity in $\mathrm{V} 1$ during locomotion, but in the absence of visual stimuli, also presents an approach to study nonvisual-related cortical dynamics that could either be motor related or are otherwise spontaneous. The large and unbiased sampling obtained through population imaging enables the identification of sparse representations. Through this, small subsets of V1 cells have been observed to respond to abrupt switches from closed- to open-loop visual stimuli (Keller et al., 2012), suggesting that these cells respond to a mismatch between the presented visual stimuli and the expected visual representation based on the locomotion. Neurons correlated to distinct

Early work has so far been focused on the influence of locomotion on sensory processing in V1. Visual stimuli presented to moving animals in relation to spherical treadmill movement can either be in an open loop (where visual input is presented without taking into account locomotion) or a closed loop (where locomotion drives the motion of visual input as to mimic the visual field flow). Open-loop paradigms are often used to map visual receptive fields (Niell and Stryker, 2010; Andermann et al., 2011; Keller et al., 2012; Ayaz et al., 2013), whereas closed-loop paradigms are used to examine the relationship between locomotion and visual input (Keller et al., 2012). Several studies have demonstrated that locomotion increases the firing rate of cells in V1 (Niell and Stryker, 2010; Andermann et al., 2011; Keller et al., 2012; Ayaz et al., 2013), which occurs, at least to some degree, through noradrenergic input (Polack et al., 2013). Whether di- phases of running were also observed. However, locomotiverelated neurons lacked any spatial organization in V1, unlike seen in other brain regions (Dombeck et al., 2009; Mukamel et al., 2009). The additional use of GECIs for chronic imaging has also allowed new investigations on cortical plasticity after changes in sensory experience. By using locomotion to assay cortical activity levels, it was found that nonvisual-related activity drops in V1 after complete retinal lesion and recovers in a homeostatic manner over the subsequent $48 \mathrm{~h}$ (Keck et al., 2013).

Visual stimuli can also be presented as virtual environments, updated by changes in trackball speed and direction, in which animals can navigate (Dombeck et al., 2007, 2010; Harvey et al., 2009, 2012; Ravassard et al., 2013). This provides a framework in which virtual mazes can be presented where locomotion serves as 
readout for decision making. The use of delay periods during choice-based reward tasks has been useful in distinguishing neuronal activity related to processing sensory evidence, decision making, working memory, and action. Virtual environments can be designed to create tasks with delay periods in the trial structure by placing extended corridors that separate an area containing reward-related stimuli from the reward site. The delay period in this case represents the time needed to traverse this extended corridor. "Stretching" the trial structure across space and time during two-photon calcium imaging has been particularly useful in allowing distinct cognitive processes to be resolved by compensating for the current limitations in imaging temporal resolution and calcium indicator kinetics. Through such approaches, sequence-based circuit dynamics representing a mouse's decision to turn left or right in a virtual T-maze have been discovered in posterior parietal cortex before the action of turning (Harvey et al., 2012). The use of virtual reality also allows for individual components underlying spatial coding to be dissected. A comparison of hippocampal place cell activity in virtual versus real environments suggests that distal visual and nonvestibular self-motion cues that are preserved in virtual reality are sufficient to provide spatial selectivity, but vestibular and other sensory cues present in real-world environments are required to fully activate the place-cell population (Ravassard et al., 2013). Overall, imaging head-fixed animals in virtual reality provides a mean to study the cortical circuits underlying spatial navigation, working memory, and decision making.

\section{Imaging neuronal activity in freely behaving rodents using miniature microscopes}

For decades, neuroscientists have been recording neuronal spiking activity in freely behaving rodents using wire electrodes, an approach that has led to many seminal discoveries, such as place cells in the hippocampus and grid cells in medial entorhinal cortex (O'Keefe and Dostrovsky, 1971; Hafting et al., 2005). Functional optical imaging in freely behaving rodents draws on the same idea: relating neuronal activity to self-determined behavior, but with additional advantages of circuit-access described previously. However, implementing this idea requires the fabrication of a microscope small and light enough to be mounted onto the head of the animal without significantly interfering with the animal's behavior. To be useful for investigating neural activity, the microscope has to permit stable imaging with sufficient speed and resolution to detect action potential-evoked $\mathrm{Ca}^{2+}$ transients in neuronal populations, with single-cell resolution.

Miniaturized two-photon microscopes consist of a removable head-mounted microscope containing an objective lens and scanning system that is then mounted on a head-plate system secured to the rodent's skull. Excitation light from the Ti:sapphire light source is "shaped" and delivered via a flexible fiber optic tether, whereas resulting emitted light can be either collected by a head-mounted photomultiplier tube (Helmchen et al., 2001) or with an additional optical fiber (Flusberg et al., 2005; Engelbrecht et al., 2008; Piyawattanametha et al., 2009; Sawinski et al., 2009). Although these microscopes maintain the advantages of using two-photon excitation, such as optical sectioning and the ability to image deep into the cortex, trade-offs currently exist between their optical performance and their size. So far, systems only suited to be carried by animals $>70$ g (e.g., rats) have been demonstrated to achieve $\mathrm{Ca}^{2+}$ imaging with cellular resolution during freely moving behavior (Sawinski et al., 2009).

Recently, an integrated fluorescence microscope has been developed that incorporates all the optical components of a fluorescence microscope within a $\sim 2 \mathrm{~g}$ head-mounted housing (Ghosh et al., 2011). This one-photon microscope is composed of mass-produced parts such as a bright LED-based light source and a complementary metal-oxide semiconductor image sensor, which have facilitated its fabrication and com- 
mercialization. The electrical wires that transmit power and data to and from the microscope provide greater flexibility in animal movement than tethering used in fiber optic microscopes. These devices enable imaging with greater optical sensitivity, field of view, resolution, and stability than previous one-photon microscopes (Flusberg et al., 2008). However, the inherent limitations of one-photon imaging in optical sectioning and depth penetration restrict the brain areas that can be noninvasively imaged with cellular resolution. Despite these limitations, this approach is well suited for imaging superficial structures and has been used to image cerebellar Purkinje neurons during freely behaving conditions, which has revealed the existence of large-scale synchronized $\mathrm{Ca}^{2+}$ spiking in microzones during locomotion and grooming (Ghosh et al., 2011).

A recent study combined the integrated microscope with a chronic microendoscopy mouse preparation to access deeper areas of the brain (Barretto et al., 2011) to monitor GCamp3expressing CA1 hippocampal neurons and longitudinally assay the dynamics of hippocampal place cells (Fig. 5). The authors asked a basic question un-addressable with previous techniques: To what extent is the CA1 place cell representation of a familiar environment stable (or changing) over the long term? The study tracked the place fields of thousands of CA1 hippocampal neurons over 1 month as mice repeatedly explored a familiar linear track (Ziv et al., 2013). The results revealed an unexpected degree of dynamism in the spatial code: on each day, the ensemble representation of this environment involved a unique subset of cells. Only a small portion of the place cells $(\sim 15-25 \%)$ overlapped between any two of these subsets and retained the same place fields, which were sufficient to preserve an accurate spatial representation across weeks.

The possibility of imaging under freely moving conditions provides an opportunity to study cortical function under behavioral contexts usually constrained or precluded under the head-fixed condition, such as self-determined and social behavior. In the absence of experimentally restricted behavior, greater emphasis must also be placed on the development of behavior tracking and analysis tools that cover the range of possible behaviors to be related to neuronal activity. For example, a miniaturized ocular-videography system has recently been developed that uses two lightweight head-mounted cameras for recording eye movements in rats (Wallace et al., 2013). This system has shown that during free movement, eye movements reflect a trade-off between detailed vision and panoramic surveillance that compromises the rat's capacity for binocular fusion and that these eye movements are substantially reduced when head movement is restricted. This form of eye movement fundamentally differs from that of other mammalian species whose eye movements are coordinated to fixate on visual targets (Leigh and Zee, 1999). How the cortex handles such different active viewing conditions across species is an open question, but such examples illustrate how freely moving behavior can reveal aspects of biological processes otherwise hindered under more controlled conditions and the need for imaging technology for observing cortical function under such contexts.

\section{Conclusion and outlook}

In this review, we have provided a glimpse of some of the many exciting recent developments that illustrate the complementary strengths of calcium imaging in neuronal populations during rodent behavior. Behavior is vast, complex, and evolves over time and its representation in the cortex can be sparse and highly variable. The ability to simultaneously monitor a large set of neurons of identified types chronically over time is critical in providing the resolution and statistical power to attack questions involving microcircuit processing across short and long time scales during behavior.

Although still nascent in its application, these paradigms have already provided new insights into and directions for studying mammalian cortical function, and its use will only grow in the years to come. The experiments provided here as examples are still reductionist by design: sampling specific subpopulations under well controlled conditions. However, these paradigms extend the spectrum of experimental approaches to that in which one can essentially "witness" the brain in action through multiple behavioral contexts while measuring sufficient numbers of parameters to make relevant comparisons to yield meaningful insight. Perhaps a greater challenge that emerges is finding the means to analyze and interpret the large, complex datasets that are generated. Already, each new study published is seemingly accompanied by a unique method for analyzing calcium signals and its relationship to stimulus or behavior. Whereas such diversity fosters new ways of gaining insight into biological questions, it can also be problematic for standardizing datasets, comparing and building consensus on the interpretation of results. Hopefully, as more studies are conducted, a common framework in which data can be easily analyzed and shared across research groups will emerge.

Looking forward, multiple avenues exist for incorporating current and emerging technologies to expand the range of questions that could be addressed with these paradigms. Variations on decision-making tasks originally established in primates, as well as tasks unique to rodent studies, provide a battery of behaviors for monitoring cortical activity during different cognitive demands. The combination of calcium imaging with optogenetic or pharmacogenetic manipulation of neural activity in specific cell types enables the causal investigation of the function role of circuit components on both behavior and cortical processing (Rogan and Roth, 2011; Packer et al., 2012; Prakash et al., 2012; Wilson et al., 2012). Ongoing improvements in two-photon microscopy and head-mounted microscopes will allow neuronal populations of greater numbers across larger and deeper brain regions to be monitored (Mittmann et al., 2011; Peron et al., 2012). Although high-speed random access scanning still requires methods for detecting and correcting for brain motion to be practical under awake conditions, the use of multiple spatiotemporal multiplexed beams to perform high-speed frame scanning serves as a viable alternative for increasing the temporal resolution for monitoring network dynamics (Cheng et al., 2011). The steady improvement of voltage-sensitive fluorescence proteins suggests that a micron-scale, all-optical electrical readout and manipulation of cortical activity may also be on the horizon (Akemann et al., 2012; Kralj et al., 2012). All these diverse tools represent a new experimental vocabulary that will benefit neuroscientists' quest for understanding the neural basis of behavior and help to answer such questions as "What does the cortex do?"

\section{References}

Akemann W, Mutoh H, Perron A, Park YK, Iwamoto Y, Knöpfel T (2012) Imaging neural circuit dynamics with a voltage-sensitive fluorescent protein. J Neurophysiol 108:2323-2337. CrossRef Medline

Andermann ML, Kerlin AM, Reid RC (2010) Chronic cellular imaging of mouse visual cortex during operant behavior and passive viewing. Front Cell Neurosci 4:3. CrossRef Medline 
Andermann ML, Kerlin AM, Roumis DK, Glickfeld LL, Reid RC (2011) Functional specialization of mouse higher visual cortical areas. Neuron 72:1025-1039. CrossRef Medline

Ayaz A, Saleem AB, Schölvinck ML, Carandini M (2013) Locomotion controls spatial integration in mouse visual cortex. Curr Biol 23:890-894. CrossRef Medline

Barretto RP, Ko TH, Jung JC, Wang TJ, Capps G, Waters AC, Ziv Y, Attardo A, Recht L, Schnitzer MJ (2011) Time-lapse imaging of disease progression in deep brain areas using fluorescence microendoscopy. Nat Med 17:223-228. CrossRef Medline

Bock DD, Lee WC, Kerlin AM, Andermann ML, Hood G, Wetzel AW, Yurgenson S, Soucy ER, Kim HS, Reid RC (2011) Network anatomy and in vivo physiology of visual cortical neurons. Nature 471:177-182. CrossRef Medline

Bonin V, Histed MH, Yurgenson S, Reid RC (2011) Local diversity and fine-scale organization of receptive fields in mouse visual cortex. J Neurosci 31:18506-18521. CrossRef Medline

Buzsáki G (2004) Large-scale recording of neuronal ensembles. Nat Neurosci 7:446-451. CrossRef Medline

Chen JL, Carta S, Soldado-Magraner J, Schneider BL, Helmchen F (2013) Behaviour-dependent recruitment of long-range projection neurons in somatosensory cortex. Nature 499:336-340. CrossRef Medline

Chen Q, Cichon J, Wang W, Qiu L, Lee SJ, Campbell NR, Destefino N, Goard MJ, Fu Z, Yasuda R, Looger LL, Arenkiel BR, Gan WB, Feng G (2012) Imaging neural activity using Thyl-GCaMP transgenic mice. Neuron 76: 297-308. CrossRef Medline

Chen TW, Wardill TJ, Sun Y, Pulver SR, Renninger SL, Baohan A, Schreiter ER, Kerr RA, Orger MB, Jayaraman V, Looger LL, Svoboda K, Kim DS (2013) Ultrasensitive fluorescent proteins for imaging neuronal activity. Nature 499:295-300. CrossRef Medline

Chen X, Leischner U, Rochefort NL, Nelken I, Konnerth A (2011) Functional mapping of single spines in cortical neurons in vivo. Nature 475: 501-505. CrossRef Medline

Cheng A, Gonçalves JT, Golshani P, Arisaka K, Portera-Cailliau C (2011) Simultaneous two-photon calcium imaging at different depths with spatiotemporal multiplexing. Nat Methods 8:139-142. CrossRef Medline

Dahmen HJ (1980) A simple apparatus to investigate the orientation of walking insects. Experientia 36:685-687. CrossRef

Dombeck DA, Khabbaz AN, Collman F, Adelman TL, Tank DW (2007) Imaging large-scale neural activity with cellular resolution in awake, mobile mice. Neuron 56:43-57. CrossRef Medline

Dombeck DA, Graziano MS, Tank DW (2009) Functional clustering of neurons in motor cortex determined by cellular resolution imaging in awake behaving mice. J Neurosci 29:13751-13760. CrossRef Medline

Dombeck DA, Harvey CD, Tian L, Looger LL, Tank DW (2010) Functional imaging of hippocampal place cells at cellular resolution during virtual navigation. Nat Neurosci 13:1433-1440. CrossRef Medline

Engelbrecht CJ, Johnston RS, Seibel EJ, Helmchen F (2008) Ultra-compact fiber-optic two-photon microscope for functional fluorescence imaging in vivo. Opt Express 16:5556-5564. CrossRef Medline

Evarts EV (1968) Relation of pyramidal tract activity to force exerted during voluntary movement. J Neurophysiol 31:14-27. Medline

Flusberg BA, Jung JC, Cocker ED, Anderson EP, Schnitzer MJ (2005) In vivo brain imaging using a portable 3.9 gram two-photon fluorescence microendoscope. Opt Lett 30:2272-2274. CrossRef Medline

Flusberg BA, Nimmerjahn A, Cocker ED, Mukamel EA, Barretto RP, Ko TH, Burns LD, Jung JC, Schnitzer MJ (2008) High-speed, miniaturized fluorescence microscopy in freely moving mice. Nat Methods 5:935-938. CrossRef Medline

Ghosh KK, Burns LD, Cocker ED, Nimmerjahn A, Ziv Y, Gamal AE, Schnitzer MJ (2011) Miniaturized integration of a fluorescence microscope. Nat Methods 8:871-878. CrossRef Medline

Glickfeld LL, Andermann ML, Bonin V, Reid RC (2013) Cortico-cortical projections in mouse visual cortex are functionally target specific. Nat Neurosci 16:219-226. CrossRef Medline

Greenberg DS, Kerr JN (2009) Automated correction of fast motion artifacts for two-photon imaging of awake animals. J Neurosci Methods 176: 1-15. CrossRef Medline

Greenberg DS, Houweling AR, Kerr JN (2008) Population imaging of ongoing neuronal activity in the visual cortex of awake rats. Nat Neurosci 11:749-751. CrossRef Medline
Grewe BF, Langer D, Kasper H, Kampa BM, Helmchen F (2010) High-speed in vivo calcium imaging reveals neuronal network activity with nearmillisecond precision. Nat Methods 7:399-405. CrossRef Medline

Hafting T, Fyhn M, Molden S, Moser MB, Moser EI (2005) Microstructure of a spatial map in the entorhinal cortex. Nature 436:801-806. CrossRef Medline

Harvey CD, Collman F, Dombeck DA, Tank DW (2009) Intracellular dynamics of hippocampal place cells during virtual navigation. Nature 461: 941-946. CrossRef Medline

Harvey CD, Coen P, Tank DW (2012) Choice-specific sequences in parietal cortex during a virtual-navigation decision task. Nature 484:62-68. CrossRef Medline

Helmchen F, Denk W (2005) Deep tissue two-photon microscopy. Nat Methods 2:932-940. CrossRef Medline

Helmchen F, Fee MS, Tank DW, Denk W (2001) A miniature headmounted two-photon microscope. High-resolution brain imaging in freely moving animals. Neuron 31:903-912. CrossRef Medline

Hira R, Ohkubo F, Ozawa K, Isomura Y, Kitamura K, Kano M, Kasai H, Matsuzaki M (2013) Spatiotemporal dynamics of functional clusters of neurons in the mouse motor cortex during a voluntary movement. J Neurosci 33:1377-1390. CrossRef Medline

Histed MH, Carvalho LA, Maunsell JH (2012) Psychophysical measurement of contrast sensitivity in the behaving mouse. J Neurophysiol 107: 758-765. CrossRef Medline

Hofer SB, Ko H, Pichler B, Vogelstein J, Ros H, Zeng H, Lein E, Lesica NA, Mrsic-Flogel TD (2011) Differential connectivity and response dynamics of excitatory and inhibitory neurons in visual cortex. Nat Neurosci 14:1045-1052. CrossRef Medline

Holtmaat A, Bonhoeffer T, Chow DK, Chuckowree J, De Paola V, Hofer SB, Hübener M, Keck T, Knott G, Lee WC, Mostany R, Mrsic-Flogel TD, Nedivi E, Portera-Cailliau C, Svoboda K, Trachtenberg JT, Wilbrecht L (2009) Long-term, high-resolution imaging in the mouse neocortex through a chronic cranial window. Nat Protoc 4:1128-1144. CrossRef Medline

Horikawa K, Yamada Y, Matsuda T, Kobayashi K, Hashimoto M, Matsu-ura T, Miyawaki A, Michikawa T, Mikoshiba K, Nagai T (2010) Spontaneous network activity visualized by ultrasensitive $\mathrm{Ca}(2+)$ indicators, yellow Cameleon-Nano. Nat Methods 7:729-732. CrossRef Medline

Huber D, Gutnisky DA, Peron S, O'Connor DH, Wiegert JS, Tian L, Oertner TG, Looger LL, Svoboda K (2012) Multiple dynamic representations in the motor cortex during sensorimotor learning. Nature 484:473-478. CrossRef Medline

Jarosiewicz B, Schummers J, Malik WQ, Brown EN, Sur M (2012) Functional biases in visual cortex neurons with identified projections to higher cortical targets. Curr Biol 22:269-277. CrossRef Medline

Jia H, Rochefort NL, Chen X, Konnerth A (2010) Dendritic organization of sensory input to cortical neurons in vivo. Nature 464:1307-1312. CrossRef Medline

Kaifosh P, Lovett-Barron M, Turi GF, Reardon TR, Losonczy A (2013) Septo-hippocampal GABAergic signaling across multiple modalities in awake mice. Nat Neurosci 16:1182-1184. CrossRef Medline

Kandel ER, Markram H, Matthews PM, Yuste R, Koch C (2013) Neuroscience thinks big (and collaboratively). Nat Rev Neurosci 14:659-664. CrossRef Medline

Katona G, Szalay G, Maák P, Kaszás A, Veress M, Hillier D, Chiovini B, Vizi ES, Roska B, Rózsa B (2012) Fast two-photon in vivo imaging with three-dimensional random-access scanning in large tissue volumes. Nat Methods 9:201-208. CrossRef Medline

Keck T, Keller GB, Jacobsen RI, Eysel UT, Bonhoeffer T, Hubener M (2013) Synaptic scaling and homoeostatic plasticity in the mouse visual cortex in vivo. Neuron. In press.

Keller GB, Bonhoeffer T, Hübener M (2012) Sensorimotor mismatch signals in primary visual cortex of the behaving mouse. Neuron 74:809-815. CrossRef Medline

Kerlin AM, Andermann ML, Berezovskii VK, Reid RC (2010) Broadly tuned response properties of diverse inhibitory neuron subtypes in mouse visual cortex. Neuron 67:858-871. CrossRef Medline

Kerr JN, Denk W (2008) Imaging in vivo: watching the brain in action. Nat Rev Neurosci 9:195-205. CrossRef Medline

Knöpfel Knopfel T (2012) Genetically encoded optical indicators for the analysis of neuronal circuits. Nat Rev Neurosci 13:687-700. CrossRef Medline 
Ko H, Hofer SB, Pichler B, Buchanan KA, Sjöström PJ, Mrsic-Flogel TD (2011) Functional specificity of local synaptic connections in neocortical networks. Nature 473:87-91. CrossRef Medline

Ko H, Cossell L, Baragli C, Antolik J, Clopath C, Hofer SB, Mrsic-Flogel TD (2013) The emergence of functional microcircuits in visual cortex. Nature 496:96-100. CrossRef Medline

Komiyama T, Sato TR, O'Connor DH, Zhang YX, Huber D, Hooks BM, Gabitto M, Svoboda K (2010) Learning-related fine-scale specificity imaged in motor cortex circuits of behaving mice. Nature 464:1182-1186. CrossRef Medline

Kralj JM, Douglass AD, Hochbaum DR, Maclaurin D, Cohen AE (2012) Optical recording of action potentials in mammalian neurons using a microbial rhodopsin. Nat Methods 9:90-95. CrossRef Medline

Langer D, Helmchen F (2012) Post hoc immunostaining of GABAergic neuronal subtypes following in vivo two-photon calcium imaging in mouse neocortex. Pflugers Arch 463:339-354. CrossRef Medline

Lee SH, Kwan AC, Zhang S, Phoumthipphavong V, Flannery JG, Masmanidis SC, Taniguchi H, Huang ZJ, Zhang F, Boyden ES, Deisseroth K, Dan Y (2012) Activation of specific interneurons improves V1 feature selectivity and visual perception. Nature 488:379-383. CrossRef Medline

Leigh RJ, Zee DS (1999) The neurology of eye movements. New York: Oxford UP.

Li Y, Lu H, Cheng PL, Ge S, Xu H, Shi SH, Dan Y (2012) Clonally related visual cortical neurons show similar stimulus feature selectivity. Nature 486:118-121. CrossRef Medline

LoTurco J, Manent JB, Sidiqi F (2009) New and improved tools for in utero electroporation studies of developing cerebral cortex. Cereb Cortex 19 [Suppl 1]:i120-i125.

Luo L, Callaway EM, Svoboda K (2008) Genetic dissection of neural circuits. Neuron 57:634-660. CrossRef Medline

Mank M, Santos AF, Direnberger S, Mrsic-Flogel TD, Hofer SB, Stein V, Hendel T, Reiff DF, Levelt C, Borst A, Bonhoeffer T, Hübener M, Griesbeck O (2008) A genetically encoded calcium indicator for chronic in vivo two-photon imaging. Nat Methods 5:805-811. CrossRef Medline

Mao T, O'Connor DH, Scheuss V, Nakai J, Svoboda K (2008) Characterization and subcellular targeting of GCaMP-type genetically-encoded calcium indicators. PLoS One 3:e1796. CrossRef Medline

Margolis DJ, Lütcke H, Schulz K, Haiss F, Weber B, Kügler S, Hasan MT, Helmchen F (2012) Reorganization of cortical population activity imaged throughout long-term sensory deprivation. Nat Neurosci 15:15391546. CrossRef Medline

Mason AC, Oshinsky ML, Hoy RR (2001) Hyperacute directional hearing in a microscale auditory system. Nature 410:686-690. CrossRef Medline

Mayrhofer JM, Skreb V, von der Behrens W, Musall S, Weber B, Haiss F (2013) Novel two-alternative forced choice paradigm for bilateral vibrotactile whisker frequency discrimination in head-fixed mice and rats. J Neurophysiol 109:273-284. CrossRef Medline

Miri A, Daie K, Burdine RD, Aksay E, Tank DW (2011) Regression-based identification of behavior-encoding neurons during large-scale optical imaging of neural activity at cellular resolution. J Neurophysiol 105:964980. CrossRef Medline

Mittmann W, Wallace DJ, Czubayko U, Herb JT, Schaefer AT, Looger LL, Denk W, Kerr JN (2011) Two-photon calcium imaging of evoked activity from L5 somatosensory neurons in vivo. Nat Neurosci 14:1089-1093. CrossRef Medline

Mukamel EA, Nimmerjahn A, Schnitzer MJ (2009) Automated analysis of cellular signals from large-scale calcium imaging data. Neuron 63:747760. CrossRef Medline

Nagai T, Ibata K, Park ES, Kubota M, Mikoshiba K, Miyawaki A (2002) A variant of yellow fluorescent protein with fast and efficient maturation for cell-biological applications. Nat Biotechnol 20:87-90. CrossRef Medline

Niell CM, Stryker MP (2010) Modulation of visual responses by behavioral state in mouse visual cortex. Neuron 65:472-479. CrossRef Medline

O'Connor DH, Clack NG, Huber D, Komiyama T, Myers EW, Svoboda K (2010a) Vibrissa-based object localization in head-fixed mice. J Neurosci 30:1947-1967. CrossRef Medline

O'Connor DH, Peron SP, Huber D, Svoboda K (2010b) Neural activity in barrel cortex underlying vibrissa-based object localization in mice. Neuron 67:1048-1061. CrossRef Medline
O'Connor DH, Hires SA, Guo ZV, Li N, Yu J, Sun QQ, Huber D, Svoboda K (2013) Neural coding during active somatosensation revealed using illusory touch. Nat Neurosci 16:958-965. CrossRef Medline

Ohtsuki G, Nishiyama M, Yoshida T, Murakami T, Histed M, Lois C, Ohki K (2012) Similarity of visual selectivity among clonally related neurons in visual cortex. Neuron 75:65-72. CrossRef Medline

O’Keefe J, Dostrovsky J (1971) The hippocampus as a spatial map. Preliminary evidence from unit activity in the freely-moving rat. Brain Res 34: 171-175. CrossRef Medline

Osakada F, Mori T, Cetin AH, Marshel JH, Virgen B, Callaway EM (2011) New rabies virus variants for monitoring and manipulating activity and gene expression in defined neural circuits. Neuron 71:617-631. CrossRef Medline

Packer AM, Peterka DS, Hirtz JJ, Prakash R, Deisseroth K, Yuste R (2012) Two-photon optogenetics of dendritic spines and neural circuits. Nat Methods 9:1202-1205. CrossRef Medline

Peron SP, Iyer V, Guo Z, Chen TW, Kim D, Huber D, Svoboda K (2012) Towards imaging complete representations of whisker touch in the mouse barrel cortex. Soc Neurosci Abstr 38:677.12.

Petreanu L, Gutnisky DA, Huber D, Xu NL, O'Connor DH, Tian L, Looger L, Svoboda K (2012) Activity in motor-sensory projections reveals distributed coding in somatosensation. Nature 489:299-303. CrossRef Medline

Piyawattanametha W, Cocker ED, Burns LD, Barretto RP, Jung JC, Ra H, Solgaard O, Schnitzer MJ (2009) In vivo brain imaging using a portable $2.9 \mathrm{~g}$ two-photon microscope based on a microelectromechanical systems scanning mirror. Opt Lett 34:2309-2311. CrossRef Medline

Polack PO, Friedman J, Golshani P (2013) Cellular mechanisms of brain state-dependent gain modulation in visual cortex. Nat Neurosci 16:13311339. CrossRef Medline

Prakash R, Yizhar O, Grewe B, Ramakrishnan C, Wang N, Goshen I, Packer AM, Peterka DS, Yuste R, Schnitzer MJ, Deisseroth K (2012) Twophoton optogenetic toolbox for fast inhibition, excitation and bistable modulation. Nat Methods 9:1171-1179. CrossRef Medline

Ravassard P, Kees A, Willers B, Ho D, Aharoni D, Cushman J, Aghajan ZM, Mehta MR (2013) Multisensory control of hippocampal spatiotemporal selectivity. Science 340:1342-1346. CrossRef Medline

Rogan SC, Roth BL (2011) Remote control of neuronal signaling. Pharmacol Rev 63:291-315. CrossRef Medline

Sato TR, Svoboda K (2010) The functional properties of barrel cortex neurons projecting to the primary motor cortex. J Neurosci 30:4256-4260. CrossRef Medline

Sawinski J, Wallace DJ, Greenberg DS, Grossmann S, Denk W, Kerr JN (2009) Visually evoked activity in cortical cells imaged in freely moving animals. Proc Natl Acad Sci U S A 106:19557-19562. CrossRef Medline

Seelig JD, Chiappe ME, Lott GK, Dutta A, Osborne JE, Reiser MB, Jayaraman V (2010) Two-photon calcium imaging from head-fixed Drosophila during optomotor walking behavior. Nat Methods 7:535-540. CrossRef Medline

Shusterman R, Smear MC, Koulakov AA, Rinberg D (2011) Precise olfactory responses tile the sniff cycle. Nat Neurosci 14:1039-1044. CrossRef Medline

Smear M, Shusterman R, O'Connor R, Bozza T, Rinberg D (2011) Perception of sniff phase in mouse olfaction. Nature 479:397-400. CrossRef Medline

Stevenson PA, Dyakonova V, Rillich J, Schildberger K (2005) Octopamine and experience-dependent modulation of aggression in crickets. J Neurosci 25:1431-1441. CrossRef Medline

ThévenazP, Ruttimann UE, Unser M (1998) A pyramid approach to subpixel registration based on intensity. IEEE Trans Image Process 7:27-41. CrossRef Medline

Vogelstein JT, Watson BO, Packer AM, Yuste R, Jedynak B, Paninski L (2009) Spike inference from calcium imaging using sequential Monte Carlo methods. Biophys J 97:636-655. CrossRef Medline

Vogelstein JT, Packer AM, Machado TA, Sippy T, Babadi B, Yuste R, Paninski L (2010) Fast nonnegative deconvolution for spike train inference from population calcium imaging. J Neurophysiol 104:3691-3704. CrossRef Medline

Wallace DJ, Greenberg DS, Sawinski J, Rulla S, Notaro G, Kerr JN (2013) Rats maintain an overhead binocular field at the expense of constant fusion. Nature 498:65-69. CrossRef Medline 
Wall NR, Wickersham IR, Cetin A, De La Parra M, Callaway EM (2010) Monosynaptic circuit tracing in vivo through Cre-dependent targeting and complementation of modified rabies virus. Proc Natl Acad Sci U S A 107:21848-21853. CrossRef Medline

Wickersham IR, Lyon DC, Barnard RJ, Mori T, Finke S, Conzelmann KK, Young JA, Callaway EM (2007) Monosynaptic restriction of transsynaptic tracing from single, genetically targeted neurons. Neuron 53:639647. CrossRef Medline

Wilson NR, Runyan CA, Wang FL, Sur M (2012) Division and subtraction by distinct cortical inhibitory networks in vivo. Nature 488:343-348. CrossRef Medline

Wurtz RH (1968) Visual cortex neurons: response to stimuli during rapid eye movements. Science 162:1148-1150. CrossRef Medline

Xu NL, Harnett MT, Williams SR, Huber D, O'Connor DH, Svoboda K, Magee JC (2012) Nonlinear dendritic integration of sensory and motor input during an active sensing task. Nature 492:247-251. CrossRef Medline

Yaksi E, Friedrich RW (2006) Reconstruction of firing rate changes across neuronal populations by temporally deconvolved $\mathrm{Ca} 2+$ imaging. Nat Methods 3:377-383. CrossRef Medline

Yu YC, He S, Chen S, Fu Y, Brown KN, Yao XH, Ma J, Gao KP, Sosinsky GE, Huang K, Shi SH (2012) Preferential electrical coupling regulates neocortical lineagedependent microcircuit assembly. Nature 486:113-117. CrossRef Medline

Zariwala HA, Borghuis BG, Hoogland TM, Madisen L, Tian L, De Zeeuw CI, Zeng H, Looger LL, Svoboda K, Chen TW (2012) A Cre-dependent GCaMP3 reporter mouse for neuronal imaging in vivo. J Neurosci 32: 3131-3141. CrossRef Medline

Ziv Y, Burns LD, Cocker ED, Hamel EO, Ghosh KK, Kitch LJ, El Gamal A, Schnitzer MJ (2013) Long-term dynamics of CA1 hippocampal place codes. Nat Neurosci 16:264-266. CrossRef Medline 